\title{
Designing competitivity activity model through the strategic agility approach in a turbulent environment
}

Fine!

Emidia Vagnoni is

Professor of Strategic

Management Accounting

at the Department of

Economics and

Management, University

of Ferrara, Ferrara, Italy.

Soheila Khoddami is

based at the Faculty of

Management, University

of Economic Sciences,

Tehran, Iran.
Received 7 March 2016 Revised 9 September 2016 Accepted 12 September 2016

\begin{abstract}
Purpose - This paper aims to introduce and test a model of shaping strategic agility based on dynamic capabilities such as information technology (IT) competencies, entrepreneurial alertness and acuity market to improve firms' competitive activity.

Design/methodology/approach - A study based on a quantitative approach has been designed. Data have been collected through closed questionnaires from a sample of firms. The study has been conducted in the electronics industry in Italy based on the dynamism of the setting. Through SPSS-AMOS application, path analysis has been performed to conduct a first assessment of the theoretical model.
\end{abstract}

Findings - The dimensions of strategic agility are relevant capabilities for improving competitive activity. Furthermore, increasing strategic agility in the three dimensions (customer, operational and partnering) depends on the ability to improve other dynamic capabilities of the organization, including IT competency, systematic insight and strategic foresight. Finally, strategic agility results to be the only variable able to leverage the firm's competitive activity.

Research limitations/implications - The study presents some limitations linked to the response rate and the ability to conduct further analysis. However, it highlights the main dimensions that managers and entrepreneurs should develop to improve the competitive activities of the firm.

Practical implications - The paper allows at address practitioners' need to identify the main variable to leverage to increase firms' competitivity.

Social implications - The results of the study offer the opportunity for new reflections when designing business executives' training programs and defining recruiting pathways.

Originality/value - This is the first study that investigates strategic agility building in a turbulent environment in the Italian setting.

Keywords Italy, Dynamic capabilities, Competitive activity, IT environment, Strategic agility

Paper type Research paper

\section{Introduction}

Environmental turbulence renders systematic strategic planning more difficult for firms (Grant, 2003; Tsai and Yang, 2014). Rapid changes increase the volatility of the business environment and require flexible and creative strategies. Nowadays, firms face great environmental turbulence due to ever-evolving competition, changing technology, fluctuating demand, disruption to the supply chain caused by human-made or natural disasters and so on. High levels of environmental turbulence can paralyze a firm's operations. Turbulence comprises uncertainty and risks faced by a firm. As a consequence, managing uncertainty and reducing risk is relevant to firms' success and they are key issues. To that end, Vecchiato (2015) points out the importance of expanding our understanding of environmental uncertainty in turbulent contexts, whereas Oetinger (2004) argues that firms should attempt to reduce the impact of uncertainty by proactively anticipating change and getting equipped to manage change. The literature describes a firm's strategic agility as a way to manage unforeseen changes and risks faced by organizations. Research indicates a limited need for agility when operating in environments 
characterized by low uncertainty (Lee, 2002; Qrunfleh and Tarafdar, 2014). Competitive activity in turbulent environments is dependent on both a firm's ability to manage changes and on its flexibility (Oetinger, 2004).

According to Hamel (2007), modern management thinking was created and developed well before our time, and, in the past decades, only very little has been changed or added. How to coordinate without creating burdensome hierarchy, how to manage costs without taking away imagination and innovation and how to build both discipline and freedom at the same time are considered to be the challenges facing modern management. To thrive in an increasingly disruptive world, companies must become as strategically adaptable as they are operationally efficient (Hamel, 2007). However, this is considered very challenging (Hamel, 2007; Brown and Eisenhardt, 1998). Morgan and Page (2008) refer to strategic agility as a way to manage unexpected changes, risks and, thus, improve competitive activity. Doz and Kosonen (2010, p. 370) argue that:

[. . .] many companies fail, not because they do something wrong or mediocre, but because they keep doing what used to be the right thing for too long, and fall victim to the rigidity of their business model.

In the face of discontinuities and disruptions, convergence and intense global competition, companies need to transform their business models more rapidly, more frequently and in a more far-reaching way than in the past. Among the different interpretations of business models provided by scholars, some common themes have emerged. Zott et al. (2011) conclude that to define a business model requires a holistic approach to explain how firms do business and to explain how value is created not just captured.

Building strategic agility has emerged as a means to innovate the business model and influence the firm performance (Hojung et al., 2015). Strategic agility is different from, but not totally conflicting with, the systematic strategy approach. In its traditional sense, making a strategy means extensive planning that leads to a company strategy that will be strictly followed for several years to come. Mintzberg et al. (1998) have listed different strategic schools of thought, all of which are focused on a long-term strategy but approached from different perspectives. According to them, there are four reasons behind strategy making:

1. strategy sets direction;

2. strategy focuses effort;

3. strategy defines the organization; and

4. strategy provides consistency.

Even though strategy and strategic direction are still as important as they used to be, in the current fast-changing business environment, the long-term strategic planning and strict strategy-following mindset need to be replaced with strategic agility (Doz and Kosonen, 2010). More recently, literature has used the notion of strategic agility to interpret how successful organizations respond to specific management concerns, such as global innovation (Wilson and Doz, 2011), leadership (Doz and Brannen, 2009), beyond the just mentioned business model renewal (Doz and Kosonen, 2010).

Strategic agility requires a firm to become a knowledge factory where knowledge begets knowledge (Roth, 1996); however, this causes both advantages and disadvantages.

The literature has identified dynamic capabilities as the main tool and fundamental element for achieving agility in an organization (Sambamurthy et al., 2003). Teece (2007) defines dynamic capabilities as "the ability of organization in composing, producing and restructuring internal and external competencies of organization in order to restrain highly changing environments". Based on a few studies performed on the subject of dynamic capability in turbulent environments, it is possible to refer to dynamic capabilities such as information technology (IT) competencies, entrepreneurial alertness and market acuity (Ojha et al., 2014; Roth and Jackson, 1995; Gaglio and Katz, 2001; Tang et al., 2012). 
Considering the above arguments, this paper aims to present a model based on the dynamic capabilities of IT competencies, entrepreneurial alertness and market acuity to shape strategic agility to improve a firm's competitive activity. The conceptualization of the research model is supported by the literature:

- literature related to strategic management that forms insight into resources and dynamic capabilities;

- the entrepreneurial literature that gives insight relating to processes assigned to entrepreneurial alertness; and

- finally, the literature relating to IT competencies.

Using the abovementioned literature, the study:

- defines how dynamic capabilities such as entrepreneurial alertness, IT competencies and market acuity, shape strategic agility; and

- how strategic agility develops competitive activity in organizations.

The paper is organized as follows. After presenting the theoretical framework in Section 2, the methodology and methods are presented in Section 3. Section 4 presents the study's results; the results are discussed and conclusions drawn in Section 5.

\section{Theoretical framework}

In a competitive market, there is an urgent need to develop and improve organizations' flexibility and their ability to respond to market situations. Many companies face constant increasing and uncertain competition that is intensified by technological innovations, market environment changes and changing demands of customers. This critical situation has led to significant changes in organizations' strategic landscape and business priorities. Both traditional and contemporary business models are revised to improve competitive activity in such environments. In other words, past approaches and solutions are no longer able to address organizational challenges and external environment issues. Therefore, a company's agility is considered to be a response to organizational changes and to improving competitive activity. In fact, agility is recognized as a new paradigm for competitive organizations and enterprises. From the mid-1990s, several academics investigated agility with regard to both an organization and business. Goldman et al. (1995) refer to the external factors that challenge a business's profit, and other authors focus on strategic agility as a business's ability to quickly adapt and change in response to rapidly changing environmental conditions (Bititci et al., 1999; McGaughey, 1999; Bessant et al., 2001). Other literature has highlighted the competitive factors lying behind agility. Schonsleben (2000) considers agile firms to be those that understand how to remain competitive by means of proactive amassing of knowledge and competencies. Sambamurthy et al. (2003) described partnering agility as the ability to leverage the assets, knowledge and competencies of suppliers, distributors, contract manufacturers and logistics providers through alliances, partnerships and joint ventures. In relation to the agility of a firm, some publications stress the role of knowledge to generate abilities, so that an organization has the potential to thrive in a continuously changing business environment. Dove (2001) argues that agility is defined by the ability to manage and apply knowledge effectively, whereas Arteta and Giachetti (2004) refer to the ability to act proactively with regard to change. Setia et al. (2008) focus on an organization's ability to harness existing knowledge, assets, relationships to seize opportunities for competitive advantage. According to Doz and Kosonen (2008), strategic agility consists of strategic sensitivity, collective commitment and resource fluidity, which allow the company to "perceive early, decide quickly, and strike with strength and speed". More recently, strategic agility conceptualization has been referred to the supply chain (Lin et al., 2006; Braunscheidel and Suresh, 2009) and to the business process (Tallon, 2008). 
Studies about agility have deepened the concept of agility and the determinants of agility have been progressively identified, allowing us to operationalize the original concept and empirically investigate it.

Despite the ambiguity reflected in the range of definitions, several characteristics emerge from the literature. First, agility is best viewed as an organizational capability, a set of organizational routines and processes that produce a particular output (Dove, 2001). This implies that a firm may be less or more agile than its competitors. Second, agility implies sense, response and learn (Dove, 2001). Prior research suggests that strong sensing capabilities, responding capabilities and learning capabilities are critical to a firm's success in turbulent environments (Haeckel, 1999; Zaheer and Zaheer, 1997). Thus, organizational agility consists of three complementary dimensions, namely, sensing, responding and learning capability. Third, agility is especially important in dynamic, fast-paced environments (Zaheer and Zaheer, 1997). Hence, the ability to sense, respond quickly and learn is an important element of agility. Finally, a firm may be agile in one or more domains, such as customer-based processes, supply chain activities or systems development (Sambamurthy et al., 2003). Thus, agility can be domain-specific.

Strategic agility requires us to look both inside and outside an organization:

- looking inside an organization for understanding and using key competencies; and

- looking outside an organization for understanding of the business environment.

Sambamurthy et al. (2003) define the dimensions of strategic agility as: customer, operational (internal) and partnering agility. Dove (2001) deepens our understanding of each dimension by dividing them into three sub-dimensions, namely, sense, respond and learn. Furthermore, focusing inside the organization, the recent definition of strategic agility by Doz and Kosonen (2008) allows us to identify the operational dimension of strategic agility.

Deepening the strategic agility concept is relevant to build and enhance agility. Roberts and Grover (2012) state that agility alignment affects the efficacy of a firm's competitive actions; in particular, action efficacy is higher when sensing and responding capabilities are both high.

Thus, strategic agility results from several variables referred to as different dimensions (Figure 1).

The literature has also focused on the role of dynamic capabilities in the definition of agility in turbulent environments. Because building dynamic capabilities requires internal processes and efforts rather than acquisitions from market transactions, they are the most unique and difficult-to-imitate assets a firm can use to achieve and sustain competitive advantage (Griffith and Harvey, 2001).

Table I summarizes dynamic capabilities based on the field of study and the business characteristics identified by authors in the literature. Each author emphasizes specific dynamic capabilities in the organization: Sambamurthy et al. (2003) focus on digital options, whereas Rosenzweig and Roth (2007) investigated knowledge channels, market acuity and fluid partnering. Koch (2010) referred to entrepreneurial alertness and to digitized process. Karakas (2009) stems from the new paradigm of digital online ecosystem or mega-platform to introduce new technologies where users create and share knowledge, innovate and collaborate together.

Market acuity becomes a critical factor in ensuring the success and continued existence of a business. Even in environments that are relatively more stable, an understanding of the market is essential as all products need to satisfy the needs of the customers and be relevant. Firms that are more knowledgeable of market conditions are necessarily more in tune with changing customer needs and are therefore in a much better position to meet market expectations (Ojha et al., 2014). 
Figure 1 Strategic agility

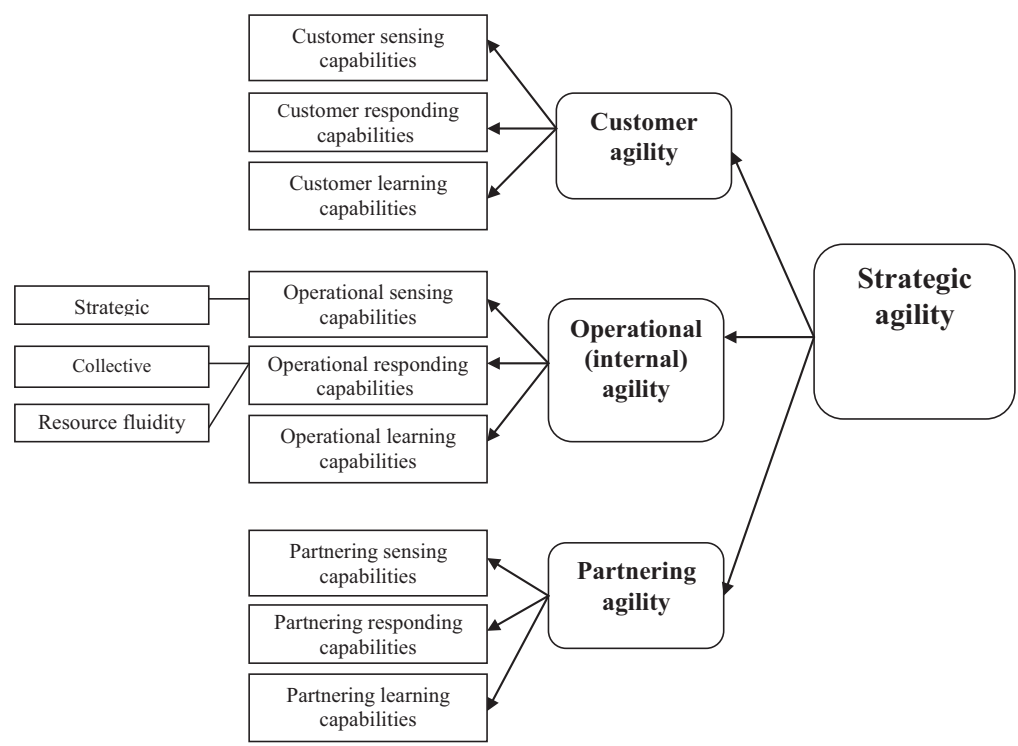

Table I Dynamic capabilities in literature

Dynamic capability

Author

Digital options

Sambamurthy et al. (2003)

Entrepreneurial alertness, IT dynamic infrastructure

Knowledge channels, market acuity, fluid partnering

Virtual integration, IT process systems

Entrepreneurial alertness, digitized process

Raschke and Smith (2007)

Rosenzweig and Roth (2007)

Rai et al. (2006)

Koch (2010)

In the conceptual framework discussed in this section, the model of strategic agility formation is presented based on the dynamic capabilities that eventually lead to the expansion of competitive activities of an organization.

\subsection{Definition of variables}

2.1.1 Competitive activity. Rapid, simultaneous product introductions may have a negative impact on a firm's performance (Barnett and Freeman, 2001). Competitive dynamics researchers have recognized this dilemma by conceptualizing and measuring various aspects of competitive activity, such as action repertoire complexity and rival action speed. Action repertoire complexity refers to the diversity of action types (e.g. pricing, marketing, product-related actions), which are executed in a span of time (Miller and Chen, 1996). Firms that take more diverse actions may achieve superior performance because diverse actions enable them to generate more unique advantages, which may be more difficult for competitors to imitate. To that end, research suggests competitive predictions as a rare capability to master (Lim, 2013). Thus, while competitive activity is often considered to be a "good" thing, capturing multiple conceptualizations and measures of competitive activity creates a richer view of organizational phenomena in the competitive dynamics arena. As summarized in Table II, the literature presents different conceptualizations and measures of competitive activity.

The key point is that competitive activity measures how well a firm senses and responds to customer-based opportunities for innovation and competitive action (Sambamurthy et al., 2003). 
Table II Conceptualizations and measures of competitive activity

\begin{tabular}{lll} 
Authors & Description & Conceptualization \\
\hline $\begin{array}{l}\text { Chen and } \\
\text { Hambrick (1995) }\end{array}$ Chen and & $\begin{array}{l}\text { The average amount of time that a firm spends to execute an } \\
\text { announced action } \\
\text { The average amount of information available about a }\end{array}$ & Action execution speed \\
$\begin{array}{l}\text { Miller and Chen } \\
\text { (1996) }\end{array}$ & $\begin{array}{l}\text { The extent to which a firm concentrates on carrying out a } \\
\text { broad range of action types in a given time period, as } \\
\text { opposed to a narrow range of action types } \\
\text { The total number of competitive actions carried out by a firm }\end{array}$ & Action visibility \\
Young et al. (1996) & $\begin{array}{l}\text { in a given time period } \\
\text { The time elapsed from the beginning to the end of a } \\
\text { sequence of action events } \\
\text { The extent to which a firm's sequential order of competitive }\end{array}$ & Action repertoire \\
Ferrier (2001) & $\begin{array}{l}\text { actions is dissimilar from one attack period to the next } \\
\text { The time elapsed between the date of a competitive action } \\
\text { carried out by the market leader and the date of competitive } \\
\text { Ferrier (2001) }\end{array}$ & Attack duration \\
& action carried out by the challenger & Attack unpredictability
\end{tabular}

Furthermore, taking multiple conceptualizations and measures of competitive activity into account provides greater understanding of the variable. This perspective has been adopted in the study framework by integrating competitive activity as the ultimate outcome of interest, as opposed to a firm's performance or competitive advantage.

2.1.2 Strategic agility. Although deeply discussed in the previous section, it is worth to point out that strategic agility consists of strategic sensitivity, collective commitment and resource fluidity, which allow the company to "perceive early, decide quickly, and strike with strength and speed" (Doz and Kosonen, 2008). Strategic agility is a complex variable that requires to consider different dimensions to be captured - customer, operational (internal) and partnering agility (Sambamurthy et al., 2003).

As argued by Nambisan (2002), customer agility can be detected considering the extent to what customers are source of new ideas, participate to the creation and shaping of innovative products and services and act as users for testing new services and products. Thus, customer agility relates to the ability of the firm to leverage the voice of the customers to define new market opportunity and competitive action. Operational agility relates to the ability of the firm to rapidly redesign the business processes based on the need to exploit new opportunities. As from Sambamurthy et al. (2003), operational agility also build on the accuracy and cost effectively criteria enabling business operations to move with greater flexibility and speed. To this end, the firm supply chain agility plays a crucial role (Glicor et al., 2016). Partnering agility is based on supply-side initiatives (Weill et al., 2002). It can be captured based on the ability of the firm to build a network to exploit opportunities through "efficient sourcing and staging of manufacturing, logistics, or customer support assets and resources" (Sambamurthy et al., 2003, p. 245). Partnering agility is also the result of the ability of the firm to modify and extend its enterprises' network to get access to knowledge, competences, assets that are not currently available.

2.1.3 Digital options. Based on the resource-based view (RBV), information systems scholars have drawn upon the dynamic capabilities framework. IT capability literature and real options conceptualize IT as a digital options generator that facilitates agility (Sambamurthy et al., 2003). Digital options refer to a set of IT-enabled capabilities in the form of digitized work processes and knowledge systems. A firm's digital options are based on its organizational IT resources and capabilities. Examples of digital "options-like" capabilities include customer-side digitization (Barua et al., 2004), supply chain process integration (Rai et al., 2006), procurement-process digitization (Mishra et al., 2007) and big data applications (Côrte-Real et al., 2016). As from Bharadwaj et al. (2013) digital technologies are fundamentally reshaping traditional business strategy as modular, distributed, cross-functional and global business processes that enable work to be carried 
out across boundaries of time, distance and function; furthermore, digital technology are contributing to transforming the structure of social relationships in both the consumer and the firm space with social media and social networking (Susarla et al., 2012).

Thus, these digital options can extend the reach and richness of a firm's knowledge and processes (Evans and Wurster, 2000; Keen, 1991), contributing to organizational agility. Fink and Neumann (2007, p. 444) refer to IT agility as "the ability to respond operationally and strategically to changes in the external environment through IT". Digitized knowledge capital captures the IT-enabled knowledge repository and the systems of interaction among organizational members to generate knowledge sharing of expertise and perspectives (Alavi and Leidner, 2001; Grove and Davenport, 2001). Digitized process capital refers to the IT-enabled organizational work processes for automating, informating and integrating activities such as customer capture, order fulfillment, supply chain, product innovation and manufacturing flow (Davenport, 1993; Garvin, 1998). For instance, customer-side digitization captures the extent to which a firm accomplishes day-to-day business activity electronically, including transactions and information exchange with customers (Barua et al., 2004). Lowry and Wilson (2016) state the relevance of the internal IT service perceptions as able to directly influence IT agility, stressing the role of the internal environment the IT manager are able to generate. A related digital capability is supply chain process integration, which is defined as the degree to which a firm has integrated its physical, financial and information flows with its supply chain partners (Rai et al., 2006). Digitized knowledge and process were conceptualized along the dimensions of reach and richness. Table III summarizes the different types of digital options as described by Sambamurthy et al. (2003).

2.1.4 Entrepreneurial alertness. Based on the development of entrepreneurial research, academics consider the identification of opportunities to be the core of entrepreneurship (Eckhardt and Shane, 2003; Fontela et al., 2006). The emphasis on both paying attention and identifying opportunities developed to a point where many academics referred to it as the heart of entrepreneurship (Gumpert and Stevenson, 1985). One of the main factors impacting this process of recognition and development of opportunity is entrepreneurial alertness. This term was first presented by Kirzner (1973) to state the identification of entrepreneurial opportunity. Then, Rai and Cardozo (1996) argued that any type of opportunity identification by an entrepreneur is based on a kind of alertness that is

Table III Types of digital options

Type of digital option

Digitized process reach

Digitized process richness

Digitized knowledge reach

Digitized knowledge richness
Definition

Extent to which a firm deploys common, integrated and connected IT-enabled processes. High reach is associated with processes that tie activity and information flows across department units, functional units, geographical regions and value network partners

Quality of information collected about transactions in the process, transparency of that information to other processes and systems that are linked to it and the ability to use that information to reengineer the process

Comprehensiveness and accessibility of codified knowledge in firm's knowledge base and the interconnected networks and systems for enhancing interactions among individuals for knowledge transfer and sharing Systems of interactions among organizational members to support sense-making, perspective sharing and development of tactic knowledge

\section{Salient information technologies}

Enterprise resource planning, supply chain management, customer relationship management, product data management

Decision support, analytic and tracking technologies

Intranets, databases and knowledge repositories

Advanced knowledge technologies, virtual video-conferencing systems, collaborative tools for knowledge sharing, etc.

Source: Sambamurthy et al. (2003) 
enhanced by information. The latter authors referred to it as entrepreneurial alertness and gave the following definition:

[. . . ] paying attention to and being sensitive to the information about the objectives, events and behavioral patterns in environment and paying special attention to the problems of producers and consumers, unsatisfied needs and new combinations of available resources.

Rai and Cardozo (1996) concluded that the increasing of alertness would improve the possibility of opportunity identification. Rhisiart et al. (2015) suggest that companies should invest in pedagogically rich scenario processes that develop the capability of managers to sense changes. Thus, the learning generated by scenario processes can strengthen the "sensing" dynamic capabilities of firms.

Finally, entrepreneurial alertness brings to a company the capability to discover market places, identify market areas that were ignored, identify opportunities and implement the opportunities based on the background of the firm in terms of activities. In this view, the capability of entrepreneurial alertness is applied to understanding the differences between entrepreneurs and managers. Rai and Cardozo (1996) identified two clear capabilities of entrepreneurial alertness - strategic foresight and systematic insight (Sambamurthy et al., 2003).

As a determinant of entrepreneurial alertness, strategic foresight has been identified as the ability to predict discreteness of commercial environments, market place, IT space, available threats and opportunities in market place and possible destructive movements of rivals. Foresight includes discovery of commercial opportunities in a coordinated manner in conceptualization of competitive activity. Moreover, foresight is vital for entrepreneurial actions because it relates to the ability of predicting and imaging the inadequacies and opportunities of the market for competitive activities (Christensen, 1997). Companies develop their strategic foresight through the personal vision of managers, their experiences and alertness of their organization regarding the innovative and competitive measures of their rivals. Appiah and Sarpong (2015) studied the role of organizational routines to influence strategic foresight integration and concluded that this is part of the process to cultivate strategic foresight. In a turbulent environment, firms should possess a strategic foresight capability to understand weak signals (Battistella, 2014) and market opportunities with a hyperactive vision; if the company fails to do this, it would lose the opportunities (Ringland, 2010). To understand that an opportunity is not suitable to be put in effect, companies are required both to be aware of the opportunity options and to know that these options are exploited through their resources and competencies. Rohrbeck (2012) identifies new potential value creation contributions of firm foresight under three general categories:

1. to trigger responses;

2. start and facilitate strategic discussions to enable strategic change; and

3. identify and support acquisition of needed strategic resources.

Thus, foresight needs to me identified and measured to understand its impact (Calof and Smith, 2012).

Systematic insight is considered another capability related to entrepreneurial alertness Sambamurthy et al., 2003); it is defined as the ability to investigate the possibility of implementing opportunities inside the company based on resources and capabilities and the ability to implement different capabilities and make a mutual relationship between them and vital opportunities of the market. Systematic insight investigates the market to determine the possibility of implementing the opportunities, helps in responding to customers' needs in a quick manner and develops innovative solutions to satisfy those needs and choosing suitable partners and leveraging their capitals (Raschke and Smith, 2007). 
2.1.5 Market acuity. As defined by Roth and Jackson (1995, p. 1731), market acuity is "an operational representation of the combined competitive strength of marketing and sales". It denotes the ability of the firm to see the competitive environment clearly and to anticipate customers' needs and wants (Kohli and Jaworski, 1990, Sambamurthy et al., 2003). The importance of market acuity is contingent on the speed of changes and dynamism (environmental uncertainty) surrounding the firm's micro environment (Froehle et al., 2000; Ojha et al., 2014). Based on the literature, market acuity is captured through factors such as the understanding of market competition, customer requirements and internal sales capabilities, as well as through the ability to understand target markets better than competitors, and to sense shifting boundaries of the industry. Some literature has mainly associated market acuity to the ability of the firm to achieve successful performance through the enhancement of new product/service development (Roth and Jackson, 1995; Menor and Roth, 2007). Thus, market acuity role has been mainly stressed with regard to the firm's performance.

\subsection{Summary and research hypothesis}

A conceptual framework has been developed (Figure 2) from the strategic agility dimensions and variables elaborated in Figure 1.

Based on RBV theory, dynamic capabilities network, IT competencies literature and available actual options, information systems thinkers have identified IT as the producer of digital options that facilitate agility (Sambamurthy et al., 2003). Digital options relate to those capabilities that are based on IT in the form of digitized business processes and knowledge systems. Digital options of a company are based on organizational resources and IT capabilities. Digital options can be classified into four categories:

1. digitized knowledge reach;

2. digitized knowledge richness;

3. digitized process reach; and

4. digitized process richness.

\section{Figure 2 Conceptual framework}

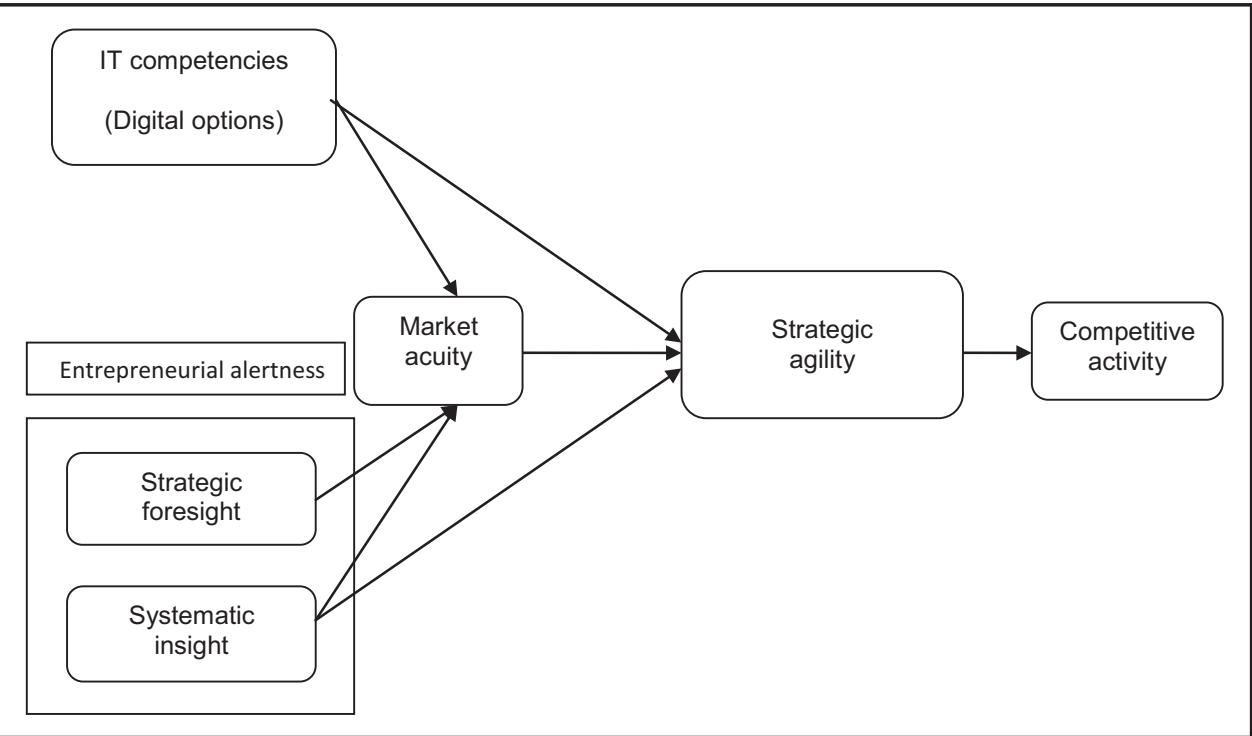


Some examples of the capabilities of digital options include:

- digitizing customer side (Barua et al., 2004);

- merging the process of supply chain (Rai et al., 2006); and

- digitizing the procurement process (Mishra et al., 2007).

Digital options improve all of the three dimensions of strategic agility. Higher levels of digitized process reach and richness improve operational agility by the coordination and the rapid commercial services sequence of the whole supply chain. The options of digital process and options of digital knowledge increase customer agility through virtual communities, customizing and presenting the ordering and delivering the knowledge of product composition (Nambisan, 2002).

The literature enables us to present the following hypothesis.

Higher levels of digitized process and knowledge improve partnering agility by the rapid coordination and searching of new competencies in value network. The knowledge dimension gains knowledge from the partners, and partners' skills and digitized process options ensure an effective integration of capabilities. As a consequence, the following hypotheses can be formulated:

H1. Digital options have a positive effect on strategic agility.

Digital options can improve market acuity in many ways (Pavlou and El Sawy, 2006). First, digital knowledge options enable the company to rapidly access new information in the market. Second, based on digital process options, correct and quick connections can be made between information and data in organization boundaries and between the actors of the supply chain, which leads the company to estimate the market collectively; hence, market acuity would increase. Third, digital options provide easy access to new and stored knowledge and facilitate the ability of the company and of supply chain's actors in detailing, interpreting and combining stored and new information, so it facilitates knowledge assimilation. Fourth, digital options capability can increase the ability of the company and its supply chain members to problem solve and enable them to build new knowledge in a direction that creates media value for real-time interaction and combining key capabilities to develop useful applications for new knowledge. Therefore, the process of knowledge transfer can be more effectively performed when digital options are available. Eventually, the capability of digital options can enhance the ability of a company and value chain members in pursuing the incentives of new products and finding new solutions, thus exploitation of a higher level of knowledge is increased.

We can describe the impact of digital options and market acuity through a bicyclic viewpoint. Digital options (particularly process options) can develop a hierarchical arrangement of bicyclic sub-systems consisting of the company and its value chain partners and facilitate their conformity and adaptability (Wang et al., 2006). Therefore, in possessing a bicyclic system, the capability of digital process options enables the company to possess a sensitive mechanism as a tool for understanding the most exact time when a media can be restricted with independent elements. When the elements existing in media become internally more limited, and more independent in terms of number, their ability to display unimportant issues would decline, so: "the sand is a better media for displaying wind than the rocks". As a result, we can say that the competency of digital options helps the company to understand market changes induced by customers, rivals and other players' behavior in the market. The above discussion leads us to present the following hypothesis:

H2. Digital options have a positive effect on market acuity.

In addition to digital options that are introduced as one of the important dynamic capabilities, entrepreneurial alertness has also an active role in continuous formation of innovation and competitive activity. Entrepreneurial alertness is the capability of a company 
for discovery of market place, identifying ignored market areas and identifying opportunities and implementing them based on the background of the company. The capability of entrepreneurial alertness also applies to understanding significant differences between entrepreneurs and managers which are related to strategic foresight and systematic insight (Sambamurthy et al., 2003). Strategic foresight is the ability to predict the discreteness of commercial environments, market place, IT space, threats and opportunities existing in the market place and possible destructive movements of rivals. Foresight is vital for entrepreneurial actions because it relates to the ability of predicting and imaging the inadequacies and opportunities of market for competitive activities (Christensen, 1997). Managers' experience and vision are relevant to develop the company strategic foresight, as well as the alertness of their organization regarding the innovative and competitive measures of their rivals. So, we can state that one of the capabilities for achieving market acuity is strategic foresight. As a consequence, it can be hypothesized that:

H3. Strategic foresight has a positive effect on market acuity.

Systematic insight is another pillar of entrepreneurial alertness, as discussed in Section 2. As it related to the ability to investigate the possibility of implementing opportunities inside the firm based on resources and capabilities, systematic insight helps in responding to customers' needs in a quick manner and development of innovative solutions to satisfy those needs (Raschke and Smith, 2007). In general, we can say that systematic insight helps market acuity and visibility of opportunities and choosing feasible opportunities to form the three dimensions of strategic agility, so the following hypotheses can be formulated:

H4. Systematic insight has a positive effect on market acuity.

H5. Systematic insight has a positive effect on strategic agility.

Market acuity is the ability of a company to observe the competitive environment clearly and predict opportunities. Market acuity enables the company to predict customers' needs and rivals' movements. Therefore, market acuity helps the company to have more sensitivity toward the priorities and requirements of customers and the market place. Being sensitive to the needs of the customers leads to a closer relationship with them and is a downward supplement for supplier partners (Powell, 1995). Closer relationships with customers depend on the strategic ability of a company to identify customers' needs and commitment extent of company in satisfying their needs. Closer relationships with customers and the market place enables the company to seek information on the priorities and needs of customers in a hyperactive manner and from which the company designs its activities in line with customers' needs; as a result, the company is more respondent than ever (Clemons et al., 2003). The insights obtained through this strong relationship with customers are used to increase the cost efficiency and operational effectiveness of the firm thanks to organizational leaders who have a better understanding of the company's landscape, and, in turn, this brings effective performance. When the companies achieve such an intimate and close relationship with customers, they can convert the needs of customers to competitive capabilities and present better products through strategic measures in which rivals can hardly intervene. Thus, the following hypotheses are formulated:

H6. Market acuity has a positive effect on strategic agility.

Competitive activity includes market-oriented movements which challenge the situation of market share or industry by innovation in products, services and channels. Companies that have a complicated set of resources and capabilities can achieve a desirable position for competitive activities. Through feeling, responding and learning of customer, operation and partnership-based opportunities, companies would show higher levels of competitive activity. As a result:

H7. Strategic agility has a positive effect on competitive activity. 


\section{Methodology}

Our aim is to present a model of shaping strategic agility based on dynamic capabilities to improve a firm's competitive activity. Our literature review enabled us to design a conceptual framework. An empirical study has been designed to test the model in the setting of Italian IT firms. The electronics industry has been chosen as a study context based on the dynamism of its products, processes and firms (Calantone et al., 2003), as well as on the relevance to foster resource efficiency (Ducatel, 2001). Thus, IT was considered to be a relevant context, where building strategic agility could be analyzed.

Data collection is based on a survey; to this end, a questionnaire was designed based on the theoretical framework variables (Appendix). Answers were organized according to a Likert scale one-five. The questionnaires were posted and addressed to the R\&D managers of the IT companies. An envelope for replying was included to make the data process gathering more effective. Companies also had the option to return the questionnaire by e-mail.

The questionnaire was sent to the entire population of IT firms with a number of employees equal or superior to 100; thus, 233 questionnaires were posted. The response rate was 26 per cent, corresponding to 60 questionnaires collected. Data were collected between March and September 2012.

Data were then analyzed using descriptive statistics and path analysis through SPSS-Statistics software 17.0 version and AMOS application. Path analysis is an extension of the regression model in which regression is done for each variable in the model as a dependent on others; it has been widely applied to test conceptual models in different disciplines and among them the managerial one (Byrne, 2001; Olobatuyi, 2006).

\section{Results}

A descriptive statistical analysis has been conducted with regard to the variables considered in the study: digital options, strategic foresight, systematic insight, market acuity, customer agility, operational agility, partner agility and competitive activity. Mean value, standard deviation, skewness and kurtosis were calculated. The results of the study are summarized in Table IV.

The score of each variable was obtained considering the average of the questionnaire items related to the variable. To analyze whether univariate normality exists, the distribution of each observed variable for skewness and kurtosis was examined. For the skewness index, absolute values greater than 3.0 are extreme (Chou et al., 1995), whereas for the kurtosis index, absolute values higher than 10.0 suggest a problem; values higher than 20.0 are considered to be extreme (Kline, 2005).

The values of skewness and kurtosis for all variables considered are in the acceptable range suggested above. Thus, the univariate normality of the variables reasonably exists. This assumption is required for the optimality of parameter estimation method used in the path model.

Table IV Descriptive statistics

\begin{tabular}{lcccrrr} 
Variables & N & Mean & SD & \multicolumn{2}{c}{ Skewness } & \multicolumn{2}{c}{ Kurtosis } \\
Standard error
\end{tabular}

PAGE 12 Foresight | VOL. 18 NO. 62016 


\subsection{Reliability analysis and hypothesis testing}

To examine the reliability of the construct used, Cronbach's alpha reliability was computed. This tests whether it may be assumed that a single common factor underlies a set of variables. The acceptable Cronbach's alpha reliability is 0.7 .

The Cronbach's alpha for all variables is 0.860 . The reliability of the scales is proved to be at a moderate to good level for all variables $(\alpha>0.7)$.

All the variables in the model have been normalized. To conduct the path analysis and test the theoretical model, the strategic agility construct has been considered as a unique variable aggregating customer agility, operational agility and partnering agility as its determinants. That variable has normalized too.

Kaiser-Mayer-Olkin (KMO) and Bartlett tests were conducted:

- KMO presented a value of 0.761 , proving the data set size adequacy; and

- Bartlett test presented a value of 0.000 showing significance for further analysis.

Then, a path analysis was conducted to explain the relations among the variables and test the theoretical model (Figure 3).

Conducting the path analysis, the $\chi^{2}$ test showing 1 degree of freedom gave the value of 5.200 , with a probability level of 0.023 . The probability level shows the fitting of the model with the conceptual one at the level of significance of $p<0.01$. Table $V$ presents the regression weights for the variables considered in the model.

\section{Figure 3 Model to be tested through path analysis}

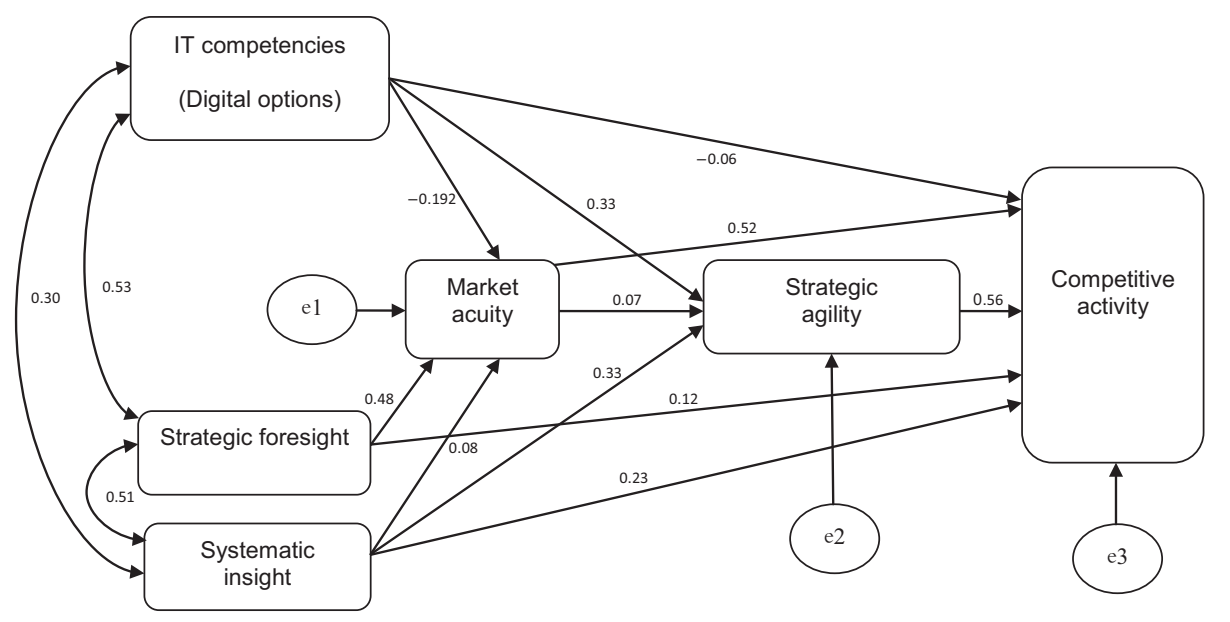

Table V Results of the path analysis

\begin{tabular}{lrrrr|} 
Model results & Estimate & \multicolumn{1}{c}{ S.E. } & \multicolumn{1}{c}{ C.R. } & $P$ \\
\hline Market acuity <- strategic foresight & 0.484 & 0.153 & 3.163 & 0.002 \\
Market acuity <- systematic insight & 0.069 & 0.156 & 0.440 & 0.660 \\
Market acuity <- digital options & -0.172 & 0.138 & -1.243 & 0.214 \\
Strategic agility <- systematic insight & 0.258 & 0.116 & 2.230 & 0.026 \\
Strategic agility <- digital options & 0.253 & 0.111 & 2.284 & 0.022 \\
Strategic agility <- market acuity & 0.064 & 0.108 & 0.592 & 0.554 \\
Competitive activity <- strategic foresight & 0.111 & 0.125 & 0.888 & 0.375 \\
Competitive activity <- systematic insight & 0.195 & 0.121 & 1.619 & 0.105 \\
Competitive activity <- digital options & -0.047 & 0.110 & -0.427 & 0.669 \\
Competitive activity <- market acuity & -0.048 & 0.111 & -0.431 & 0.667 \\
Competitive activity <- strategic agility & 0.605 & 0.140 & 4.318 & régression is \\
& & & & significant for \\
& & & & a p<0,001
\end{tabular}


The goodness of fit index has been calculated; its value results to be 0.964 , it is a value that get close to 1; thus, it allows us at considering the acceptability of the model.

\section{Discussion and conclusions}

In this paper, a model to build strategic agility has been proposed and tested based on dynamic capabilities and its relationship with competitive activities.

The statistical analysis allows us to achieve a general result regarding the relationship between the variables of the model. First, the impact of digital options (IT competency) on market acuity is not confirmed, considering the experimental data related to the Italian context. Second, it results the impact of strategic foresight on market acuity. This result indicates that one way to increase market acuity is based on the involvement of individuals in organizational positions who have both high managerial capability and entrepreneurial capabilities for predicting and forecasting the inadequacies and opportunities of the market. In addition, the company should be aware of the innovative measures of rivals. Third, the model tested did not allow at confirming the impact of systematic insight on market acuity: the hypothesis relating to the positive relationship between systematic insight and market acuity is rejected. Fourth, it is confirmed the relation between digital option and strategic agility; this suggests that digital options is one of the capabilities that helps to build an agile organization toward customers, partners and in its operational dimension. As a consequence, it can be argued that digital options are important tools for achieving the dimensions of strategic agility for an organization. To achieve the dimensions of strategic agility, companies should enhance digital options (digitized knowledge reach and richness and digitized process reach and richness) by applying related tools.

Then, based on the statistical analysis, the results indicate that systematic insight is one of the capabilities that helps the formation of strategic agility in the organizations. Consequently, the systematic insight of organizational individuals is relevant:

- the ability to investigate the feasibility of opportunities in the specific context of the company; and

- the ability to develop mutual relationships between different capabilities of the company and vital opportunities of market.

Furthermore, the relation between market acuity and strategic agility is rejected. Thus, the mediating role of market acuity to achieve strategic agility is not proved.

The analysis, then, allows at showing the impact of strategic agility on competitive activity. Based on this result, we can state that strategic agility is a relevant construct for improving competitive activity. Furthermore, to develop their competitive activity in turbulent environments, organizations should increase their strategic agility. This is consistent with the model presented, and it indicates that increasing strategic agility depends on the ability to improve other dynamic capabilities of the organization, including IT competency, strategic foresight and systematic insight.

Based on the results presented above, the final model in Figure 4 can be presented as a means to explain how IT firms, in Italy, build strategic agility and develop competitive activity.

The model confirms the relations expressed by the literature; as argued by Sambamurthy et al. (2003), digital options affect the ability of firms to launch many and varied competitive actions and that, in turn, these competitive actions are a significant antecedent of firm performance. Thus, alignment between digital options and performance is relevant, and it requires both sensing and responding capabilities as proved by Roberts and Grover (2012). Systematic insight results to be relevant for strategic agility development, too. Fostering insights into future customers' needs, industry tendencies and bridging firm's characteristics with market opportunities, allows at leveraging the firm's strategic agility, as proved by Doz and Kosonen (2010). Finally, agility - considered in its different dimensions 
Figure 4 Final research model

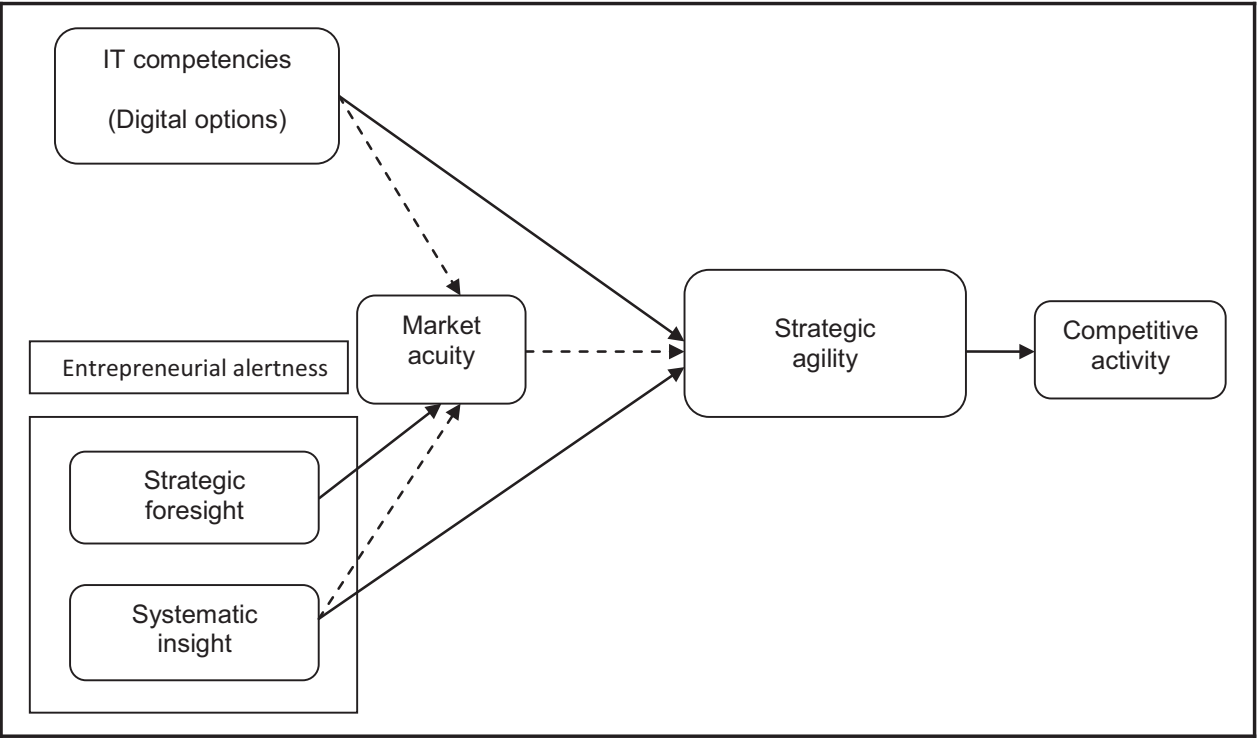

as operational, partnering and customer - contribute to respond quickly to new opportunities for innovation and competitive action. As concluded by Roberts and Grover (2014), agility alignment affects the efficacy of a firm's competitive actions.

As mentioned above, the role of market acuity to enhance strategic agility has not been confirmed in our study related to the IT context. Nevertheless, literature has stressed the role of market acuity as a relevant ability of the firm to see the competitive environment and reach top performances, that is mainly with regard to the development of competence to understand customers' need and to enhance new product development (Roth, 1996; Menor and Roth, 2007). The lack of relevant role of market acuity to enhance strategic agility could fall in the characteristics of the studied context. The IT sector is mainly characterized by advanced innovations whose development might draw more on scientific knowledge generated by research entities. As from Tödtling et al. (2009), IT firms introducing more advanced innovation rely to a higher extent on R\&D and patents, whereas firms introducing less advanced innovation rely more on knowledge exchange with the business context.

Defining and testing the conceptualized model as discussed above, allows us to draw some practical implications.

Because the results of digital options research are confirmed as a platform to build the dimensions of strategic agility capabilities, we suggest that organizations generate and use different digital options such as intranets, databases, knowledge repository, advanced knowledge technology, virtual conference systems, cooperation-based tools for sharing knowledge, planning for organizational resources, value chain, customer relation management and supporting technologies for analytical decisions and detections.

Furthermore, some implications are related to managerial competences: to enhance a firm's competitivity, we suggest that managers be employed who have not only managerial capabilities and abilities but also entrepreneurial ability in the field of opportunity identification, namely, the individuals who possess the following capabilities: those who pay attention to and are sensitive to information relating to objectives, events and behavioral patterns in the environment and pay special attention to the producers' and consumers' needs and unsatisfied needs and can generate new combinations of available resources. 
Based on this research, managers can measure their organization's strategic agility in different dimensions, so we suggest that managers monitor the strategic agility capability and detect the weaknesses to be able to be more effective toward the firm's competitivity.

The developed research model allows us to conclude that dynamic capabilities can improve the competitive activity of a firm based on the relationships among the different dynamic capabilities, thus, omitting to consider the relationships generates a failure toward an improvement in competitive activity. Finally, most of the past research only focuses on one aspect of competitive activity; in this study, we suggest that managers monitor competitive activity considering quantitatively and qualitatively. In practice, and based on the study results, the role of managers results to be crucial for firms' competitivety. That could have a twofold implication: on one hand, the study results could affect managers' training, and, on the other hand, the ability of the managers to enhance the competitive action of the firm could have societal implications, in terms of economic development, wealth creation and occupation.

Although some limitations can be associated to the study, based on the response rate and the ability to conduct further analysis, this is the first study that investigates strategic agility building in a turbulent environment in the Italian setting. The paper contributes to the literature related to how strategic agility is built in firms and presents practical implication for firms' management.

\section{References}

Alavi, M. and Leidner, D.E. (2001), "Review: knowledge management and knowledge management systems: conceptual foundations and research issues", MIS Quarterly, Vol. 25 No. 1, pp. 107-136.

Appiah, G. and Sarpong, D. (2015), "On the influence of organisational routines on strategic foresight", Foresight, Vol. 17 No. 5, pp. 512-527.

Arteta, B.M. and Giachetti, R.E. (2004), "A measure of agility as the complexity of the enterprise system", Robotics and Computer-Integrated Manufacturing, Vol. 20 No. 6, pp. 495-503.

Barnett, W.P. and Freeman, J. (2001), "Too much of a good thing? Product proliferation and organizational failure", Organization Science, Vol. 12 No. 5, pp. 539-558.

Barua, A., Konana, P., Whinston, A.B. and Yin, F. (2004), "An empirical investigation of net-enabled business value”, MIS Quarterly, Vol. 28 No. 4, pp. 585-620.

Battistella, C. (2014), "The organization of corporate foresight: a multiple case study in the telecommunication industry", Technological Forecasting \& Social Change, Vol. 87, pp. 60-79.

Bessant, J., Francis, D., Meredith, S. and Kalinsky, R. (2001), "Developing manufacturing agility in Smes", International Journal of Technology Management, Vol. 22 No. 1, pp. 28-54.

Bharadwaj, A., El Sawy, O.A., Pavlou, P.A. and Venkatraman, N.V. (2013), "Digital business strategy: toward a next generation of insights", MIS Quarterly, Vol. 37 No. 2, pp. 471-482.

Bititci, U.S., Trevor, J.T. and Ball, P.D. (1999), "The viable business structure for managing agility", International Journal of Agile Management Systems, Vol. 1 No. 3, pp. 190-202.

Braunscheidel, M.J. and Suresh, N.C. (2009), "The organizational antecedents of a firm's supply chain agility for risk mitigation and response", Journal of Operations Management, Vol. 27 No. 2, pp. 119-140.

Brown, S.L. and Eisenhardt, K.M. (1998), Competing on the Edge: Strategy as Structured Chaos, Harvard Business School Press, Boston, MA.

Byrne, B.M. (2001), Structural Equation Modeling with AMOS: Basic Concepts, Applications, and Programming, Lawrence Erlbaum Associates Publishers, Mahwah, NJ.

Calantone, R., Garcia, R. and Dröge, C. (2003), "The effects of environmental turbulence on new product development strategy planning", Journal of Product Innovation Management, Vol. 20 No. 2, pp. 90-103.

Calof, J. and Smith, J.E. (2012), "Foresight impacts from around the world: a special issue", Foresight, Vol. 14 No. 1, pp. 5-14.

Chen, M. J., and Hambrick, D. C. (1995), "Speed, stealth, and selective attack: How small firms differ from large firms in competitive behavior", Academy of Management Journal, Vol. 38, pp. 453-482. 
Chou, C.P., Bentler, P.M. and Hoyle, R.H. (Ed.) (1995), Structural Equation Modeling: Concepts, Issues, and Applications, Sage Publications, Thousand Oaks, CA.

Christensen, C.M. (1997), The Innovator's Dilemma: when New Technologies Cause Great Firms to Fail, Harvard Business School Press, Cambridge, MA.

Clemons, E.K., Gu, B. and Spitler, R. (2003), "Hyper-differentiation strategies: delivering value, retaining profits", Proceedings of the 36th Hawaii International Conference on System Sciences, Track-8.

Côrte-Real, N., Oliveira, T. and Ruivo, P. (2016), "Assessing business value of big data analytics in European firms", Journal of Business Research. In press. Available online 9 August 2016.

Davenport, T. (1993), Process Innovation: Reengineering Work Through Information Technology, Harvard Business School Press, Boston, MA

Dove, R. (2001), Response Ability: The Language, Structure, and Culture of the Agile Enterprise, John Wiley \& Sons, New York, NY.

Doz, Y. and Brannen, M.Y. (2009), "The agile leader as a fusion point", CKIR Workshop on "Leadership and Governance Innovation", Helsinki School of Economics Heslinki, Finland, 26-28 August 2009.

Doz, Y. and Kosonen, M. (2008), Fast Strategy, Wharton School Publishing, Harlow.

Doz, Y. and Kosonen, M. (2010), "Embedding strategic agility: a leadership agenda for accelerating business model renewal", Long Range Planning, Vol. 43 No. 2, pp. 370-382.

Ducatel, K. (2001), "Balance of nature? Sustainable societies in the digital economy", Foresight, Vol. 3 No. 2, pp. 123-133.

Eckhardt, J.T. and Shane, S.A. (2003), "Opportunities and entrepreneurship", Journal of Management, Vol. 29 No. 3, pp. 333-349.

Evans, P. and Wurster, T.S. (2000), Blown to Bits: How the New Economics of Information Transforms Strategy, Harvard Business School Press, Boston, MA.

Ferrier, W.J. (2001), "Navigating the competitive landscape: the drivers and consequences of competitive aggressiveness", Academy of Management Journal, Vol. 44 No. 4, pp. 858-877.

Fink, L. and Neumann, S. (2007), "Gaining agility through IT personnel capabilities: the mediating role of IT infrastructure capabilities", Journal of AIS, Vol. 8 No. 8, pp. 440-462.

Fontela, E., Guzmán, J., Pérez, M. and Santos, J. (2006), "The art of entrepreneurial foresight", Foresight, Vol. 8 No. 6, pp. 3-13.

Froehle, C.M., Roth, A.V., Chase, R.B. and Voss, C.A. (2000), "Antecedents of new service development effectiveness an exploratory examination of strategic operations choices", Journal of Service Research, Vol. 3 No. 1, pp. 3-17.

Gaglio, C.M. and Katz, J.A. (2001), "The psychological basis of opportunity identification: entrepreneurial alertness", Small Business Eeconomics, Vol. 16 No. 2, pp. 95-111.

Garvin, D.A. (1998), "The processes of organization and management", Sloan Management Review, Vol. 39 No. 4, pp. 33-50.

Glicor, D.M., Holcomb, M.C. and Feizabadi, J. (2016), "An exploration of the strategic antecedents of firm supply chain agility: the role of a firm's orientations", International Journal of Production Economics, Vol. 179, pp. 24-34.

Goldman, S.L., Nagel, R.N. and Preiss, K. (1995), Agile Competitors and Virtual Organizations: Strategies for Enriching the Customer, Van Nostrand Reinhold, New York, NY.

Grant, R.M. (2003), "Strategic planning in a turbulent environment: evidence from the oil majors", Strategic Management Journal, Vol. 24 No. 6, pp. 491-517.

Griffith, D.A. and Harvey, M.G. (2001), "A resource perspective of global dynamic capabilities", Journal of International Business Studies, Vol. 32 No. 3, pp. 597-606

Grove, V. and Davenport, T.H. (2001), "General perspective on knowledge management: fostering a research agenda", Journal of Management Information Systems, Vol. 18 No. 1, pp. 5-21.

Gumpert, D. and Stevenson, H. (1985), "The heart of entrepreneurship", Harvard Business Review, Vol. 63, pp. 85-94.

Haeckel, S.H. (1999), Adaptive Enterprise, Harvard Business School Press, Boston, MA. 
Hamel, G. (2007), The Future of Management, Harvard Business School Press, Boston, MA.

Hojung, S., Jae-Nam, L., Daesoo, K. and Hosun, R. (2015), "Strategic agility of Korean small and medium enterprises and its influence on operational and firm performance", International Journal of Production Economics, Vol. 168, pp. 181-196.

Karakas, F. (2009), "Welcome to World 2.0: the new digital ecosystem", Journal of Business Strategy, Vol. 30 No. 4, pp. 23-30.

Keen, P.G.W. (1991), Shaping the Future: Business Design through Information Technology, Harvard Business School Press, Boston, MA.

Kirzner, I.M. (1973), Competition and Entrepreneurship, University of Chicago Press, Chicago, IL.

Kline, R.B. (2005), Principles and Practice of Structural Equation Modeling, 2nd ed., The Guilford Press, New York, NY

Koch, H. (2010), "Developing dynamic capabilities in electronic marketplaces: a cross-case study", Journal of Strategic Information Systems, Vol. 19 No. 1, pp. 28-38.

Kohli, A.K. and Jaworski, B.J. (1990), "Market orientation: the construct, research propositions, and managerial implications", The Journal of Marketing, Vol. 54 No. 2, pp. 1-18.

Lee, H. (2002), "Aligning supply chain strategies with product uncertainties", California Management Review, Vol. 44 No. 3, pp. 105-119.

Lim, L.K.S. (2013), "Mapping competitive prediction capability: construct conceptualization and performance payoffs", Journal of Business Research, Vol. 66, pp. 1576-1586.

Lin, C., Chiu, H. and Chu, P. (2006), "Agility index in the supply Chain", International Journal of Production Economics, Vol. 100 No. 2, pp. 285-299.

Lowry, P.B. and Wilson, D. (2016), "Creating agile organizations through IT: the influence of internal IT service perceptions on IT service quality and IT agility", The Journal of Strategic Information System, Vol. 25 No. 3, pp. 211-226.

McGaughey, R.E. (1999), "Internet technology: contributing to agility in the twenty-first century", International Journal of Agile Management Systems, Vol. 1 No. 1, pp. 7-13.

Menor, L.J. and Roth, A.V. (2007), "New service development competence in retail banking: construct development and measurement validation", Journal of Operations Management, Vol. 25 No. 4, pp. 825-846.

Miller, D. and Chen, M.J. (1996), "Nonconformity in competitive repertoires: a sociological view of markets", Social Forces, Vol. 74 No. 4, pp. 1209-1234.

Mintzberg, H., Ahlstrand, B. and Lampel, J. (1998), Strategy Safari: A Guided Tour through the Wilds of Strategic Management, Prentice Hall, New York, NY.

Mishra, A.N., Konana, P. and Barua, A. (2007), "Antecedents and consequences of internet use in procurement: an empirical investigation of US manufacturing firms", Information Systems Research, Vol. 18 No. 1, pp. 103-120.

Morgan, R.E. and Page, K. (2008), "Managing business transformation to deliver strategic agility", Strategic Change, Vol. 17 Nos 5/6, pp. 155-168.

Nambisan, S. (2002), "Designing Virtual customer environment for new product development: toward a theory", Academy of Mmanagement Rreview, Vol. 27 No. 3, pp. 392-413.

Oetinger, B.V. (2004), "A plea for uncertainty: everybody complains about uncertainty, but it might be a good thing to have", Journal of Business Strategy, Vol. 25 No. 1, pp. 57-59.

Ojha, D., Salimath, M. and D'Souza, D. (2014), "Disaster immunity and performance of service firms: the influence of market acuity and supply network partnering", International Journal of Production Economics, Vol. 147 (Part B), pp. 385-397.

Olobatuyi, M.E. (2006), A User's Guide to Path Analysis, University Press of America.

Pavlou, P.A. and El Sawy, O. (2006), "From IT competence to competitive advantage in turbulent environments: the case of new product development", Information Systems Research, Vol. 17 No. 3, pp. 198-227.

Powell, T.C. (1995), "Total quality management as competitive advantage: a review and empirical study", Strategic Management Journal, Vol. 16 No. 1, pp. 15-37. 
Qrunfleh, S. and Tarafdar, M. (2014), "Supply chain information systems strategy: impacts on supply chain performance and firm performance", International Journal of Production Economics, Vol. 147, pp. 340-350.

Rai, A., Patnayakuni, R. and Seth, N. (2006), "Firm performance impacts of digitally-enabled supply chain integration capabilities", MIS Quarterly, Vol. 30 No. 2, pp. 225-246.

Raschke, R. and Smith, D.J. (2007), An Empirical Analysis of Business Process Agility: Examining the Relationship of IT on Business Process Agility and the Effects of Business Process Agility on Process Outcomes. Arizona State University.

Ray, S. and Cardozo, R. (1996), "Sensitivity and creativity in entrepreneurial opportunity recognition: a framework for empirical investigation", Presented at the Sixth Global Entrepreneurship Research Conference, Imperial College, London.

Rhisiart, M., Miller, R. and Brooks, S. (2015), "Learning to use the future: developing foresight capabilities through scenario processes", Technological Forecasting and Social Change, Vol. 101, pp. 124-133.

Ringland, G. (2010), "The role of scenarios in strategic foresight", Technological Forecasting and Social Change, Vol. 77 No. 9, pp. 1493-1498.

Roberts, N. and Grover, V. (2012), "Leveraging information technology infrastructure to facilitate a firm's customer agility and competitive activity: an empirical investigation", Journal of Management Information Systems, Vol. 28 No. 4, pp. 231-270.

Rohrbeck, R. (2012), "Exploring value creation from corporate-foresight activities", Futures, Vol. 44 No. 5, pp. 440-452.

Rosenzweig, E.D. and Roth, A.V. (2007), "B2B seller competence: construct development and measurement using a supply chain strategy lens", Journal of Operations Management, Vol. 25 No. 6, pp. 1311-1331.

Roth, A.V. (1996), "Achieving strategic agility through economies of knowledge", Planning Review, Vol. 24 No. 2, pp. 30-36.

Roth, A.V. and Jackson, III, W.E. (1995), "Strategic determinants of service quality and performance: evidence from the banking industry", Management Science, Vol. 41 No. 11, pp. 1720-1733.

Sambamurthy, V., Bharadwaj, A. and Grover, V. (2003), "Shaping agility through digital options: reconceptualizing the role of information technology in contemporary firms", MIS Quarterly, Vol. 27 No. 2, pp. 237-263.

Schonsleben, P. (2000), "With agility and adequate partnership strategies towards effective logistics networks", Computers in Industry, Vol. 42 No. 1, pp. 33-42.

Setia, P., Sambamurthy, V. and Closs, D.J. (2008), "Realizing business value of agile it applications: antecedents in the supply chain networks", Information Technology and Management, Vol. 9 No. 1, pp. 5-19.

Susarla, A., Oh, J.H. and Tan, Y. (2012), "Social networks and the diffusion of user-generated content: evidence from YouTube", Information Systems Research, Vol. 23 No. 1, pp. 23-41.

Tallon, P. (2008), "Inside the adapative enterprise: an information technology capabilities perspective on business process agility", Information Technology and Management, Vol. 9 No. 1, pp. 21-36.

Tang, J., Kacmar, K.M.M. and Busenitz, L. (2012), "Entrepreneurial alertness in the pursuit of new opportunities", Journal of Business Venturing, Vol. 27 No. 1, pp. 77-94.

Teece, D.J. (2007), "Explicating dynamic capabilities: the nature and microfoundations of (sustainable) enterprise performance”, Strategic Management Journal, Vol. 28 No. 13, pp. 1319-1350.

Tödtling, F., Lehner, P. and Kaufmann, A. (2009), "Do different types of innovation rely on specific kinds of knowledge interactions?", Technovation, Vol. 29 No. 1, pp. 59-71.

Tsai, K.H. and Yang, S.Y. (2014), "The contingent value of firm innovativeness for business performance under environmental turbulence", International Entrepreneurship and Management Journal, Vol. 10 No. 2, pp. 343-366.

Vecchiato, R. (2015), "Strategic planning and organizational flexibility in turbulent environments", Foresight, Vol. 17 No. 3, pp. 257-273.

Wang, E., Tai, J. and Wei, H. (2006), "A virtual integration theory of improved supply chain performance", Journal of Management Information Systems, Vol. 23 No. 2, pp. 41-64. 
Weill, P., Subramani, M. and Broadbent, M. (2002), "Building IT infrastructure for strategic agility", MIT Sloan Management Review, Vol. 1 No. 44, pp. 57-65.

Wilson, K. and Doz, Y. (2011), "Agile innovation: a footprint balancing distance and immersion", California Management Review, Vol. 53 No. 2, pp. 6-26.

Young, G., Smith, K.G. and Grimm, C.M. (1996), "'Austrian' and industrial organization perspectives on firm-level competitive activity and performance", Organization Science, Vol. 7 No. 3, pp. 243-254.

Zaheer, A. and Zaheer, S. (1997), "Catching the wave: alertness, responsiveness, and market influence in global electronic networks", Management Science, Vol. 43 No. 11, pp. 1493-1509.

Zott, C., Amit, R. and Massa, L. (2011), "The business model: recent developments and future research", Journal of Management, Vol. 37 No. 4, pp. 1019-1042.

\section{Further reading}

Hambrick, D.C. (1995), "Fragmentation and the other problems CEOs have with their top management teams", California Management Review, Vol. 37 No. 3, pp. 110-110. 


\section{Appendix}

Please determine the rate of using of each of the indicators related to digital options in your company (with putting sign in relevant option)

\begin{tabular}{|c|c|c|c|c|c|c|}
\hline number & your company ${ }_{\text {yex }}$ ith putting sign in & $\begin{array}{l}\text { Feryan } \\
\text { low }\end{array}$ & It PDion & moderate & high & $\begin{array}{l}\text { Very } \\
\text { high }\end{array}$ \\
\hline 1 & Intranets & & & & & \\
\hline 2 & Databases & & & & & \\
\hline 3 & Knowledge Repositories & & & & & \\
\hline 4 & $\begin{array}{l}\text { Virtual Video-conferencing } \\
\text { Systems }\end{array}$ & & & & & \\
\hline 5 & $\begin{array}{l}\text { Collaborative Tools for Knowledge } \\
\text { Sharing }\end{array}$ & & & & & \\
\hline 6 & $\begin{array}{l}\text { Advanced Knowledge } \\
\text { Technologies }\end{array}$ & & & & & \\
\hline 7 & Supply Chain Management(SCM) & & & & & \\
\hline 8 & Enterprise Resource planning(ERP) & & & & & \\
\hline 9 & $\begin{array}{l}\text { Customer Relationship } \\
\text { Management (CRM) }\end{array}$ & & & & & \\
\hline 10 & Product Data Management & & & & & \\
\hline 11 & Decision Support Technologies & & & & & \\
\hline 12 & Analytic Technologies & & & & & \\
\hline 13 & Tracking Technologies & & & & & \\
\hline
\end{tabular}

Please use your business unit (e.g., product/customer division) as the reference point to provide your responses about your organization.For each of the statements below, please indicate how much you agree or disagree by selecting the appropriate response

\begin{tabular}{|c|c|c|c|c|c|c|}
\hline 离 & & 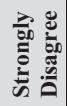 & 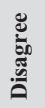 & 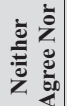 & ฮี & 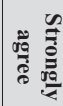 \\
\hline 14 & $\begin{array}{l}\text { You can anticipate discontinuities in the business } \\
\text { environment }\end{array}$ & & & & & \\
\hline 15 & $\begin{array}{l}\text { You have Organizational intelligence about emerging } \\
\text { information technologies and your business potential }\end{array}$ & & & & & \\
\hline 16 & $\begin{array}{l}\text { You can anticipate opportunities in the extended } \\
\text { enterprise chain }\end{array}$ & & & & & \\
\hline 17 & $\begin{array}{l}\text { You have Integrated exploration of business } \\
\text { opportunities }\end{array}$ & & & & & \\
\hline 18 & $\begin{array}{l}\text { You have Alertness to competitive innovation actions } \\
\text { by rivals }\end{array}$ & & & & & \\
\hline 19 & $\begin{array}{l}\text { You can anticipate threats and opportunities in } \\
\text { business environment }\end{array}$ & & & & & \\
\hline 20 & $\begin{array}{l}\text { You can investigate seizing opportunities within the resources } \\
\text { and capabilities of your organization }\end{array}$ & & & & & \\
\hline 21 & $\begin{array}{l}\text { You can exploit the opportunities based on resources } \\
\text { and capabilities of your organization }\end{array}$ & & & & & \\
\hline 22 & $\begin{array}{l}\text { You can consider the complex interconnections } \\
\text { among the different capabilities and marketplace } \\
\text { opportunities }\end{array}$ & & & & & \\
\hline 23 & $\begin{array}{l}\text { You review the market for feasibility of seizing the } \\
\text { opportunities }\end{array}$ & & & & & \\
\hline 24 & $\begin{array}{l}\text { You tend to predict fundamental shifts in your } \\
\text { industry }\end{array}$ & & & & & \\
\hline 25 & $\begin{array}{l}\text { You are aware of new and emerging markets that you } \\
\text { could serve in the future }\end{array}$ & & & & & \\
\hline 26 & $\begin{array}{l}\text { You know why customers are attracted to your } \\
\text { competitors }\end{array}$ & & & & & \\
\hline 27 & $\begin{array}{l}\text { You have the ability to typically foresee new } \\
\text { competitive threats and opportunities }\end{array}$ & & & & & \\
\hline 28 & You know your competitors quite well & & & & & \\
\hline 29 & $\begin{array}{l}\text { You have the ability to understand customer } \\
\text { requirements better than your competitors do. }\end{array}$ & & & & & \\
\hline 30 & $\begin{array}{l}\text { You are able to sense shifting boundaries of your } \\
\text { industry }\end{array}$ & & & & & \\
\hline 31 & $\begin{array}{l}\text { You understand target markets better than } \\
\text { competitors do }\end{array}$ & & & & & \\
\hline 32 & $\begin{array}{l}\text { You have a good understanding of competitors' } \\
\text { strengths and strategies }\end{array}$ & & & & & \\
\hline 33 & $\begin{array}{l}\text { You understand competitive environment better than } \\
\text { competitors do }\end{array}$ & & & & & \\
\hline
\end{tabular}

(continued) 


\begin{tabular}{|c|c|c|c|c|c|c|}
\hline 产 & & 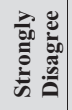 & 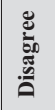 & 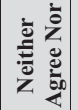 & 쁑 & 参 \\
\hline 34 & $\begin{array}{l}\text { You continuously try to discover additional needs of } \\
\text { your customers of which they are unaware }\end{array}$ & & & & & \\
\hline 35 & $\begin{array}{l}\text { You work closely with lead users who try to } \\
\text { recognize customer needs months or even years } \\
\text { before the majority of the market may recognize } \\
\text { them }\end{array}$ & & & & & \\
\hline 36 & $\begin{array}{l}\text { You extrapolate key trends to gain insight into what } \\
\text { users in a current market will need in the future }\end{array}$ & & & & & \\
\hline 37 & $\begin{array}{l}\text { You attempt to develop new ways of looking at } \\
\text { customers and their needs }\end{array}$ & & & & & \\
\hline 38 & $\begin{array}{l}\text { You sense your customers' needs even before they } \\
\text { are aware of them }\end{array}$ & & & & & \\
\hline 39 & $\begin{array}{l}\text { You continuously try to anticipate your customers' } \\
\text { needs even before they are aware of them }\end{array}$ & & & & & \\
\hline 40 & $\begin{array}{l}\text { You respond rapidly if something important happens } \\
\text { with regard to your customers }\end{array}$ & & & & & \\
\hline 41 & $\begin{array}{l}\text { You quickly implement your planned activities with } \\
\text { regard to customers }\end{array}$ & & & & & \\
\hline 42 & $\begin{array}{l}\text { You quickly react to fundamental changes with } \\
\text { regard to your customers }\end{array}$ & & & & & \\
\hline 43 & $\begin{array}{l}\text { When You find that customers would like you to } \\
\text { modify a product or service, your organization makes } \\
\text { concerted efforts to do so }\end{array}$ & & & & & \\
\hline 44 & $\begin{array}{l}\text { When You identify a new customer need, You are } \\
\text { quick to respond to it }\end{array}$ & & & & & \\
\hline 45 & $\begin{array}{l}\text { You are fast to respond to changes in your } \\
\text { customers' product or service needs }\end{array}$ & & & & & \\
\hline 46 & $\begin{array}{l}\text { You customize your products to meet customers' } \\
\text { needs }\end{array}$ & & & & & \\
\hline 47 & $\begin{array}{l}\text { You develop new product design process to meet } \\
\text { customer needs }\end{array}$ & & & & & \\
\hline 48 & $\begin{array}{l}\text { You are flexible and develop your product based on } \\
\text { customer needs }\end{array}$ & & & & & \\
\hline 49 & $\begin{array}{l}\text { Your customer can test new products of the } \\
\text { organization }\end{array}$ & & & & & \\
\hline 50 & $\begin{array}{l}\text { Your Customer can actively add information to the } \\
\text { declarative and procedural memory of your } \\
\text { organization }\end{array}$ & & & & & \\
\hline 51 & $\begin{array}{l}\text { You receive customer feedback on your } \\
\text { organization's product, service or delivery process is } \\
\text { embedded in the process }\end{array}$ & & & & & \\
\hline 52 & $\begin{array}{l}\text { Your organization regularly comes together with } \\
\text { customers to evaluate and improve processes }\end{array}$ & & & & & \\
\hline 53 & $\begin{array}{l}\text { Your organization have customer knowledge } \\
\text { management }\end{array}$ & & & & & \\
\hline 54 & $\begin{array}{l}\text { You engage in honest, open and rich dialogue around } \\
\text { strategic issues }\end{array}$ & & & & & \\
\hline 55 & You have open strategy process & & & & & \\
\hline 56 & $\begin{array}{l}\text { You set the Conflicts and conflicting objectives } \\
\text { which influence the staff to search new innovations }\end{array}$ & & & & & \\
\hline 57 & $\begin{array}{l}\text { You create scenarios related to possible future } \\
\text { developments and ways to achieve them }\end{array}$ & & & & & \\
\hline 58 & You use collective wisdom around strategic issues & & & & & \\
\hline 59 & $\begin{array}{l}\text { You organize for mutual dependency along the value } \\
\text { chain or functions, for example by giving individual } \\
\text { executives responsibility for different stages in the } \\
\text { company's value chain, instead of only giving them } \\
\text { formal responsibility for a business unit. }\end{array}$ & & & & & \\
\hline 60 & $\begin{array}{l}\text { You change roles and responsibilities within the top } \\
\text { team (Top team renewal) }\end{array}$ & & & & & \\
\hline 61 & $\begin{array}{l}\text { You have ability to encourage employees to work } \\
\text { together as a team, especially in top hierarchy of the } \\
\text { organization }\end{array}$ & & & & & \\
\hline 62 & Managers can perform multiple tasks & & & & & \\
\hline 63 & $\begin{array}{l}\text { You attract, retain and reward entrepreneurial } \\
\text { managers }\end{array}$ & & & & & \\
\hline 64 & $\begin{array}{l}\text { Members of your organization has ability in team } \\
\text { work }\end{array}$ & & & & & \\
\hline 65 & You create multiple channels for resource assessment & & & & & \\
\hline 66 & You have mobility of capital and people & & & & & \\
\hline
\end{tabular}

(continued) 


\begin{tabular}{|c|c|c|c|c|c|c|}
\hline ఏ & & 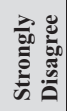 & 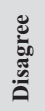 & 咅 & 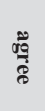 & 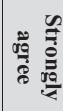 \\
\hline 67 & $\begin{array}{l}\text { You have modularity of resources which } \\
\text { Organizational resources doesn't have same size }\end{array}$ & & & & & \\
\hline 68 & $\begin{array}{l}\text { You have conversations to make revisions treat } \\
\text { market moves as experiments, analyze the findings } \\
\text { and use these lessons to revise assumptions, priorities } \\
\text { and commitments. }\end{array}$ & & & & & \\
\hline 69 & $\begin{array}{l}\text { You retain information concerning customer } \\
\text { facing events }\end{array}$ & & & & & \\
\hline 70 & $\begin{array}{l}\text { You retain information concerning past events and } \\
\text { the actions (solutions) in relation to your process } \\
\text { and/or customer }\end{array}$ & & & & & \\
\hline 71 & $\begin{array}{l}\text { Your employees can actively add information to the } \\
\text { declarative and procedural memory of your } \\
\text { organization }\end{array}$ & & & & & \\
\hline 72 & $\begin{array}{l}\text { You retain information concerning your products and } \\
\text { services }\end{array}$ & & & & & \\
\hline 73 & $\begin{array}{l}\text { Your employees are facilitated to share (tacit) } \\
\text { knowledge among each other }\end{array}$ & & & & & \\
\hline 74 & $\begin{array}{l}\text { You receives feedback from your employees (for } \\
\text { instance via surveys) }\end{array}$ & & & & & \\
\hline 75 & $\begin{array}{l}\text { You receive employees feedback on the } \\
\text { organization's product, service or delivery process is } \\
\text { embedded in the process }\end{array}$ & & & & & \\
\hline 76 & $\begin{array}{l}\text { Your employees regularly come together to evaluate } \\
\text { and improve processes }\end{array}$ & & & & & \\
\hline 77 & You collect business information from your partner & & & & & \\
\hline 78 & $\begin{array}{l}\text { You meet with your partners in order to find out what } \\
\text { their needs will be in the future. }\end{array}$ & & & & & \\
\hline 79 & You screen possible partners & & & & & \\
\hline 80 & $\begin{array}{l}\text { You use external data sources from partners to sense } \\
\text { changing patterns or developments }\end{array}$ & & & & & \\
\hline 81 & $\begin{array}{l}\text { You involves their partners as a source of innovative } \\
\text { ideas for new products and services }\end{array}$ & & & & & \\
\hline 82 & You registers requests and complaints from partners & & & & & \\
\hline 83 & $\begin{array}{l}\text { You receive feedback from partners(for instance via } \\
\text { surveys) }\end{array}$ & & & & & \\
\hline 84 & $\begin{array}{l}\text { You enable your partners to experiment with new } \\
\text { products or services }\end{array}$ & & & & & \\
\hline 85 & $\begin{array}{l}\text { You have ability to involve your partners directly in } \\
\text { product design \& testing }\end{array}$ & & & & & \\
\hline 86 & $\begin{array}{l}\text { Your partners can reconfigure products or services } \\
\text { themselves }\end{array}$ & & & & & \\
\hline 87 & $\begin{array}{l}\text { Your partners have procedures and tools in place to } \\
\text { diagnose events and generate possible responses }\end{array}$ & & & & & \\
\hline 88 & You can mobilize your partners quickly and easily & & & & & \\
\hline 89 & $\begin{array}{l}\text { You enable your partners to monitor progress and } \\
\text { status of the response }\end{array}$ & & & & & \\
\hline 90 & $\begin{array}{l}\text { The business processes carried out by your partner } \\
\text { can be updated quickly, when the need arises }\end{array}$ & & & & & \\
\hline 91 & You can create alliances with your partners & & & & & \\
\hline 92 & You can share your risk with your partners & & & & & \\
\hline 93 & $\begin{array}{l}\text { Your external partners can actively add information } \\
\text { to the declarative and procedural memory of your } \\
\text { organization }\end{array}$ & & & & & \\
\hline 94 & $\begin{array}{l}\text { Your external partners are facilitated to share } \\
\text { information and experience among each other }\end{array}$ & & & & & \\
\hline 95 & $\begin{array}{l}\text { You receive partner feedback on the organization's } \\
\text { product, service or delivery process is embedded in } \\
\text { the process }\end{array}$ & & & & & \\
\hline 96 & $\begin{array}{l}\text { You took quick action when something important } \\
\text { happened with regard to your organization }\end{array}$ & & & & & \\
\hline 97 & You quickly implemented your planned activities & & & & & \\
\hline 98 & $\begin{array}{l}\text { You were fast to take action in response to changes } \\
\text { in your customers' product or service needs. }\end{array}$ & & & & & \\
\hline 99 & $\begin{array}{l}\text { When You identified a new opportunity, You were } \\
\text { swift to execute the appropriate action }\end{array}$ & & & & & \\
\hline
\end{tabular}

Please determine the rate of bellow indicators of competitive activity in your company during the one year (with putting sign in relevant option)

(continued) 


\begin{tabular}{|c|c|c|c|c|c|c|}
\hline number & index & $\begin{array}{l}\text { Very } \\
\text { low }\end{array}$ & low & moderate & high & $\begin{array}{l}\text { Very } \\
\text { high }\end{array}$ \\
\hline 101 & $\begin{array}{l}\text { The number of new pricing actions } \\
\text { (e.g., major price increases, } \\
\text { discounts, rebates) }\end{array}$ & & & & & \\
\hline 102 & $\begin{array}{l}\text { The number of new marketing } \\
\text { actions (e.g., rewards, promotions, } \\
\text { marketing campaigns) }\end{array}$ & & & & & \\
\hline 103 & $\begin{array}{l}\text { The number of new product actions } \\
\text { (e.g., new product/service launch, } \\
\text { roll out, release) }\end{array}$ & & & & & \\
\hline 104 & $\begin{array}{l}\text { The number of new capacity actions } \\
\text { (e.g., changes in capacity or output of } \\
\text { products or services) }\end{array}$ & & & & & \\
\hline 105 & $\begin{array}{l}\text { The number of new alliance actions } \\
\text { (e.g., new joint venture, alliance, } \\
\text { distribution agreement) }\end{array}$ & & & & & \\
\hline 106 & $\begin{array}{l}\text { Percentage of pricing actions which } \\
\text { exploit opportunities }\end{array}$ & & & & & \\
\hline 107 & $\begin{array}{l}\text { Percentage of marketing actions } \\
\text { which exploit opportunities }\end{array}$ & & & & & \\
\hline 108 & $\begin{array}{l}\text { Percentage of product actions which } \\
\text { exploit opportunities }\end{array}$ & & & & & \\
\hline 109 & $\begin{array}{l}\text { Percentage of capacity actions which } \\
\text { exploit opportunities }\end{array}$ & & & & & \\
\hline 110 & $\begin{array}{l}\text { Percentage of alliance actions which } \\
\text { exploit opportunities }\end{array}$ & & & & & \\
\hline 111 & $\begin{array}{l}\text { Range of pricing action types in a } \\
\text { given time period }\end{array}$ & & & & & \\
\hline 112 & $\begin{array}{l}\text { Range of marketing action types in } \\
\text { a given time period }\end{array}$ & & & & & \\
\hline 113 & $\begin{array}{l}\text { Range of product action types in a } \\
\text { given time period }\end{array}$ & & & & & \\
\hline 114 & $\begin{array}{l}\text { Range of capacity action types in a } \\
\text { given time period }\end{array}$ & & & & & \\
\hline 115 & $\begin{array}{l}\text { Range of alliance action types in a } \\
\text { given time period }\end{array}$ & & & & & \\
\hline
\end{tabular}

\section{About the authors}

Emidia Vagnoni is Professor of Strategic Management accounting at the University of Ferrara. Her research interests consider both public sector organizations and small medium enterprises, as from her publications' record. Emidia is also supervising a number of PhD students on the performance measurement and strategic control issues. Emidia Vagnoni is the corresponding author and can be contacted at: vgnmde@unife.it

Soheila Khoddami is a Researcher at the University of Economic Sciences in the Islamic Republic of Iran. She has been working on strategic management both in her country and abroad.

For instructions on how to order reprints of this article, please visit our website: www.emeraldgrouppublishing.com/licensing/reprints.htm Or contact us for further details: permissions@emeraldinsight.com 


\section{AUTHOR QUERIES}

\section{AUTHOR PLEASE ANSWER ALL QUERIES}

AQau-Please confirm the given-names and surnames are identified properly by the colours. = Given-Name, $\mathbf{a}=$ Surname The colours are for proofing purposes only. The colours will not appear online or in print.

AQ1 - Please note that the following citations are not found in the reference list. Please provide full details for these citations: Chen and Hambrick (1995).

AQ2- Please provide first column head for Table IV and V and also provide significance of $* * *$ and italic data in Table V.

AQ3 - Please provide volume, issue and page range for reference: Côrte-Real et al. (2016). 